\title{
Tinting Efficiency of Various Food Dyes in Colour Intensification of Tuberose (Polianthes tuberose L.) Spikes
}

\author{
P. Prasanth ${ }^{*}$, Z. Salma and S. Praneeth Kumar
}

Floricultural Research Station, AICRP on Floriculture, SKLTSHU, ARI, Rajendranagar, Hyderabad - 500 030, India

*Corresponding author

\section{A B S T R A C T}

\section{Keywords}

Tuberose, Tinting,

Food dyes,

Immersion time

\section{Article Info}

Accepted:

12 August 2020

Available Online:

10 September 2020
An experiment was conducted to study the effect of food dyes in tinting of tuberose spikes at Floricultural Research Station, SKLTSHU, Rajendranagar, Hyderabad during 2015 -16 to 2017-18 for three years. The results of the experiment revealed that, food dye uptake quantity (ml) did not differ significantly due to food dyes and duration of dipping (Time) in dye solution. Similarly, number of florets open per spike and floret diameter (mm) was also not influenced by duration of dipping (Time) of flower spikes. However, maximum number of florets open per spike was recorded in Orange red $4 \%$ (18.40) and minimum in control (17.01). Orange red $4 \%$ and two hours of dipping registered maximum number of florets open per spike (19.45). Food dyes did not differ significantly for vase life of spikes, but one hour duration dipping recorded more vase life (4.48 days) and was on par with two hours dipping. The colour intensity differed due to different food dyes, the maximum intensity was observed in $8 \%$ concentration for two hours of dipping in all dyes. Among the different food dyes tuberose flower spikes dipped in kesar yellow, apple green and orange red at $8 \%$ had shown maximum intensity of colour in two hours of dipping time.

\section{Introduction}

Tuberose an ornamental bulbous commercial flower crop belongs to Amaryllididaceae family. The flower florets of tuberose are very beautiful and fragrant in nature, even though coloured species of tuberose are available but they are not suitable for commercial cultivation. The species Polianthes tuberose L. with white florets is widely cultivated in the world due to its attractive and fragrant florets on long spikes. Tuberose is used both as cut flower and loose flower in the domestic market. The loose flowers are mainly used in preparation of garlands, gajras and floral ornaments. The coloured florets of tuberose to green, blue, red, orange is having great demand among consumers for preparation of many value added products. In view of this tinting of tuberose flower spikes is better option using different dyes which are safe is very important.

Tinting a value addition technique in white flower crops due to absence of colour pigments. Imparting colours to flowers with 
food (edible) dyes improves the visual appeal of these flowers and increase their economic value. This technique provides a great range of colours and enhances the aesthetic sense. For decorative purpose where a particular colour is desired, tinting of white flower is an easy way of obtaining the color of interest, where as certified synthetic food colours are less expensive, less hazardous and impart an intense and uniform colour to flowers (Sowmeya et al., 2017). Tinting techniques was already experimented in tuberose by using various food dyes. (Sambandha Murthy and Appavu, 1980; Kumar and Bhattacharjee, 2004; Mekala et al., 2012, Suresh et al., 2016; Safeena et al., 2016; Sweta Kumari and Prahlad Deb, 2018).

Tinting is usually done at the retailer level, however, if farmers adopt this technique at farm level and impart various colours to tuberose spikes it will increase value of the produce and fetch good price in market which in turn earn higher returns with this value addition technology. Hence, in view of the above facts the present experiment was carried to study the efficacy of different food dyes and their duration of dipping in imparting the colours to tuberose spikes.

\section{Materials and Methods}

The experiment was conducted in Laboratory of Floriculture Research Station, AICRP on Floriculture Centre, Agricultural Research Institute, SKLTSHU, Rajendranagar, Hyderabad for three years during 2015-16 to 2017-18. The cultivar used for the study was Hyderabad Double, six food colours viz., Lemon yellow, Kesar yellow, Apple green, Orange red, Rose pink and Rasp berry red at two concentrations of four and eight per cent were taken in the study. Further, the immersion (dipping) time of one, two and three hours was also studied. The experiment was designed in Completely Randomised
Design in factorial concept with three replications.

Uniform spikes of $60 \mathrm{~cm}$ length with basal 23 florets open were harvested and used in the study. The harvested spikes were placed in the $200 \mathrm{ml}$ flasks with $100 \mathrm{ml}$ of dye solutions of 4 and 8 per cent for three durations of time. After specified duration of immersion in one, two and three hours was completed each set of thirteen treatments, the spikes were transferred to $500 \mathrm{ml}$ glass bottles containing $200 \mathrm{ml}$ of distilled water to study vase life.

The vase life was studied by recording opening of florets (No.), floret diameter $(\mathrm{cm})$, vase life (days) and colour intensity (RHS colour chart). The data recorded was statistically analysed using OPSTAT software and the difference of means was compared at five per cent level of significance.

\section{Results and Discussion}

The mean quantity of food dye up take with respect to food dyes concentration and different times of immersion were found statistically non significant (Table 1). As there was variation in uptake of dyes by tuberose spikes during different immersion times lead to non significant results in overall uptake of food dyes.

Florets open per spike during vase life period was found significant (Table 2). The mean maximum number of florets open per spike (18.40) was recorded in $\mathrm{T}_{8}$ - Orange Red 4 per cent. It was on par with apple green at both concentrations ( $4 \& 8 \%$ ), orange red 8 and Raspberry red 4 per cent. The minimum number of florets open per spike (17.01) was noticed in $\mathrm{T}_{1}$ - Control. The edible dyes might have not interfered with the activities of the florets opening in the spikes thus no significant effect on the opening of the floret was observed during vase life period. 
Table.1 Influence of food dyes and immersion time on uptake of dye (ml) in tuberose spike

\begin{tabular}{|c|c|c|c|c|c|}
\hline \multicolumn{2}{|c|}{ Treatments } & \multicolumn{4}{|c|}{ Food dye uptake quantity (ml) } \\
\hline & & \multirow{2}{*}{$\begin{array}{c}\text { 1HR } \\
2.04\end{array}$} & \multirow{2}{*}{$\begin{array}{c}2 \mathrm{HR} \\
1.68\end{array}$} & \multirow{2}{*}{$\begin{array}{c}3 H R \\
2.83 \\
\end{array}$} & \multirow{2}{*}{$\begin{array}{c}\text { Mean } \\
2.18\end{array}$} \\
\hline $\mathbf{T}_{1}$ & Control & & & & \\
\hline $\mathbf{T}_{2}$ & Lemon yellow - $4 \%$ & 2.82 & 1.90 & 1.87 & 2.20 \\
\hline $\mathbf{T}_{3}$ & Lemon Yellow - 8\% & 3.55 & 1.52 & 2.10 & 2.39 \\
\hline $\mathbf{T}_{4}$ & Kesar Yellow - 4\% & 2.19 & 1.71 & 2.25 & 2.05 \\
\hline $\mathbf{T}_{5}$ & Kesar Yellow $-8 \%$ & 2.32 & 2.76 & 2.27 & 2.45 \\
\hline $\mathbf{T}_{6}$ & Apple green $-4 \%$ & 2.69 & 2.34 & 2.19 & 2.41 \\
\hline $\mathbf{T}_{7}$ & Apple green $-8 \%$ & 2.65 & 2.50 & 1.97 & 2.37 \\
\hline $\mathbf{T}_{8}$ & Orange red $-4 \%$ & 2.22 & 1.78 & 1.61 & 1.87 \\
\hline $\mathbf{T}_{9}$ & Orange red $-8 \%$ & 2.29 & 1.71 & 1.79 & 1.93 \\
\hline $\mathbf{T}_{10}$ & Rose pink $-4 \%$ & 3.25 & 3.12 & 3.11 & 3.16 \\
\hline $\mathbf{T}_{11}$ & Rose pink $-8 \%$ & 2.29 & 3.11 & 1.26 & 2.22 \\
\hline $\mathbf{T}_{12}$ & Raspberry red $-4 \%$ & 2.25 & 1.45 & 1.84 & 1.85 \\
\hline \multirow{6}{*}{$\mathbf{T}_{13}$} & Raspberry red $-8 \%$ & 3.16 & 2.21 & 2.73 & 2.70 \\
\hline & Mean & 2.59 & 2.14 & 2.14 & \\
\hline & & \multicolumn{2}{|c|}{ SE (m) } & \multicolumn{2}{|c|}{$\mathrm{CD}(\mathrm{P}=\mathbf{0 . 0 5})$} \\
\hline & Food dyes & \multicolumn{2}{|c|}{0.15} & \multicolumn{2}{|c|}{ NS } \\
\hline & Time & \multicolumn{2}{|c|}{0.31} & \multicolumn{2}{|c|}{ NS } \\
\hline & FxT & \multicolumn{2}{|c|}{0.53} & \multicolumn{2}{|c|}{ NS } \\
\hline
\end{tabular}

Table.2 Influence of food dyes and immersion time on Number of florets open and floret diameter of tuberose spike

\begin{tabular}{|c|c|c|c|c|c|c|c|c|c|}
\hline \multicolumn{2}{|c|}{ Treatments } & \multicolumn{4}{|c|}{ No. of florets open / spike } & \multicolumn{4}{|c|}{ Floret diameter $(\mathrm{cm})$} \\
\hline & & 1HR & 2HR & 3HR & Mean & 1HR & 2HR & 3HR & Mean \\
\hline $\mathbf{T}_{1}$ & Control & 16.53 & 17.84 & 16.67 & 17.01 & 3.39 & 3.82 & 3.35 & 3.52 \\
\hline $\mathbf{T}_{2}$ & Lemon yellow - $4 \%$ & 17.86 & 17.11 & 16.69 & 17.22 & 3.47 & 3.76 & 3.32 & 3.52 \\
\hline $\mathbf{T}_{3}$ & Lemon Yellow $-8 \%$ & 16.66 & 17.39 & 17.58 & 17.21 & 3.30 & 3.88 & 3.16 & 3.44 \\
\hline $\mathbf{T}_{4}$ & Kesar Yellow - 4\% & 16.41 & 17.52 & 18.42 & 17.45 & 3.97 & 4.10 & 3.53 & 3.87 \\
\hline $\mathbf{T}_{5}$ & Kesar Yellow $-8 \%$ & 17.00 & 17.71 & 17.22 & 17.31 & 3.87 & 4.20 & 3.55 & 3.87 \\
\hline $\mathbf{T}_{6}$ & Apple green - $4 \%$ & 19.29 & 18.36 & 17.44 & 18.36 & 3.64 & 4.04 & 3.61 & 3.76 \\
\hline $\mathbf{T}_{7}$ & Apple green $-8 \%$ & 18.24 & 17.43 & 17.22 & 17.63 & 3.67 & 3.25 & 3.48 & 3.46 \\
\hline $\mathbf{T}_{8}$ & Orange red $-4 \%$ & 17.26 & 19.45 & 18.48 & 18.40 & 3.41 & 3.12 & 3.63 & 3.39 \\
\hline $\mathbf{T}_{9}$ & Orange red $-8 \%$ & 17.12 & 18.86 & 18.22 & 18.07 & 3.76 & 3.54 & 3.80 & 3.70 \\
\hline $\mathbf{T}_{10}$ & Rose pink - $4 \%$ & 18.38 & 17.22 & 16.41 & 17.34 & 3.70 & 3.70 & 3.65 & 3.68 \\
\hline $\mathbf{T}_{11}$ & Rose pink - 8\% & 16.46 & 16.15 & 18.47 & 17.03 & 3.56 & 3.66 & 3.60 & 3.61 \\
\hline $\mathbf{T}_{12}$ & Raspberry red $-4 \%$ & 18.02 & 17.43 & 19.53 & 18.33 & 3.34 & 3.67 & 3.81 & 3.61 \\
\hline \multirow{6}{*}{$\mathbf{T}_{13}$} & Raspberry red $-8 \%$ & 17.12 & 17.69 & 17.35 & 17.39 & 3.45 & 3.94 & 3.35 & 3.58 \\
\hline & Mean & 17.41 & 17.70 & 17.67 & & 3.58 & 3.74 & 3.53 & \\
\hline & & \multicolumn{2}{|c|}{ SE (m) } & \multicolumn{2}{|c|}{$\mathrm{CD}(\mathbf{P}=\mathbf{0 . 0 5})$} & \multicolumn{2}{|c|}{ SE (m) } & \multicolumn{2}{|c|}{$\mathrm{CD}(\mathrm{P}=\mathbf{0 . 0 5})$} \\
\hline & Food dyes & \multicolumn{2}{|c|}{0.29} & \multicolumn{2}{|c|}{0.816} & \multicolumn{2}{|c|}{0.094} & \multicolumn{2}{|c|}{ NS } \\
\hline & Time & \multicolumn{2}{|c|}{0.603} & \multicolumn{2}{|c|}{ NS } & \multicolumn{2}{|c|}{0.196} & \multicolumn{2}{|c|}{ NS } \\
\hline & FxT & \multicolumn{2}{|c|}{1.045} & \multicolumn{2}{|c|}{2.944} & \multicolumn{2}{|c|}{0.34} & \multicolumn{2}{|c|}{ NS } \\
\hline
\end{tabular}


Table.3 Influence of food dyes and immersion time on vase life of tuberose spike

\begin{tabular}{|c|c|c|c|c|c|}
\hline \multicolumn{2}{|c|}{ Treatments } & \multicolumn{4}{|c|}{ Vase Life (days) } \\
\hline & & \multirow{2}{*}{$\begin{array}{c}\text { 1HR } \\
5.12\end{array}$} & \multirow{2}{*}{$\begin{array}{c}\text { 2HR } \\
4.93\end{array}$} & \multirow{2}{*}{$\begin{array}{c}\text { 3HR } \\
4.06\end{array}$} & \multirow{2}{*}{$\begin{array}{c}\text { Mean } \\
\mathbf{4 . 7 0}\end{array}$} \\
\hline$T_{1}$ & Control & & & & \\
\hline $\mathbf{T}_{2}$ & Lemon yellow - $4 \%$ & 4.66 & 4.03 & 4.03 & 4.24 \\
\hline $\mathbf{T}_{3}$ & Lemon Yellow - 8\% & 4.66 & 4.30 & 4.12 & 4.36 \\
\hline $\mathbf{T}_{4}$ & Kesar Yellow - 4\% & 4.93 & 4.03 & 3.22 & 4.06 \\
\hline $\mathbf{T}_{5}$ & Kesar Yellow - 8\% & 4.52 & 3.59 & 3.54 & 3.88 \\
\hline $\mathbf{T}_{6}$ & Apple green - $4 \%$ & 3.97 & 3.37 & 3.51 & 3.62 \\
\hline $\mathbf{T}_{7}$ & Apple green $-8 \%$ & 4.22 & 3.94 & 3.66 & 3.94 \\
\hline $\mathbf{T}_{8}$ & Orange red $-4 \%$ & 4.65 & 4.03 & 3.94 & 4.21 \\
\hline $\mathbf{T}_{9}$ & Orange red $-8 \%$ & 3.91 & 3.56 & 3.37 & 3.61 \\
\hline$T_{10}$ & Rose pink $-4 \%$ & 4.53 & 4.18 & 4.73 & 4.48 \\
\hline$T_{11}$ & Rose pink $-8 \%$ & 4.18 & 4.21 & 4.11 & 4.17 \\
\hline$T_{12}$ & Raspberry red $-4 \%$ & 4.56 & 3.74 & 3.56 & 3.95 \\
\hline \multirow[t]{6}{*}{$\mathbf{T}_{13}$} & Raspberry red $-8 \%$ & 4.35 & 3.58 & 3.30 & 3.74 \\
\hline & Mean & 4.48 & 3.96 & 3.78 & \\
\hline & & \multicolumn{2}{|c|}{ SE $(\mathbf{m})$} & \multicolumn{2}{|c|}{$\mathrm{CD}(\mathrm{P}=0.05)$} \\
\hline & Food dyes & \multicolumn{2}{|c|}{0.105} & \multicolumn{2}{|c|}{ NS } \\
\hline & Time & \multicolumn{2}{|c|}{0.219} & \multicolumn{2}{|c|}{0.617} \\
\hline & FxT & \multicolumn{2}{|c|}{0.379} & \multicolumn{2}{|c|}{1.069} \\
\hline
\end{tabular}

Table.4 Influence of food dyes and immersion time on intensity of colour of tuberose spike

\begin{tabular}{|c|c|c|c|c|}
\hline \multirow{2}{*}{\multicolumn{2}{|c|}{ Treatments }} & \multicolumn{3}{|c|}{ Colour Intensity - RHS Colour chart } \\
\hline & & 1HR & 2HR & 3HR \\
\hline $\mathbf{T}_{1}$ & Control & N 155 D White & N 155 D White & N 155 D White \\
\hline $\mathbf{T}_{2}$ & Lemon yellow - $4 \%$ & 1 D Green Yellow & 7 D Yellow & $6 \mathrm{C}$ Yellow \\
\hline $\mathbf{T}_{3}$ & Lemon Yellow $-8 \%$ & 3D Yellow & 8 B Yellow & 7 C Yellow \\
\hline $\mathbf{T}_{4}$ & Kesar Yellow - 4\% & 22 C Yellow Orange & 15 C Yellow Orange & 22 B Yellow Orange \\
\hline $\mathbf{T}_{5}$ & Kesar Yellow $-8 \%$ & 21 B Yellow Orange & $21 \mathrm{C}$ Yellow Orange & 23 A Yellow Orange \\
\hline $\mathbf{T}_{6}$ & Apple green - $4 \%$ & 140 B Green & 140 D Green & 142 B Green \\
\hline $\mathbf{T}_{7}$ & Apple green $-8 \%$ & 140 C Green & 141 D Green & 142 A Green \\
\hline $\mathbf{T}_{8}$ & Orange red $-4 \%$ & 24 C Orange & 29 C Orange & 29 B Orange \\
\hline $\mathbf{T}_{9}$ & Orange red $-8 \%$ & 25 C Orange & 29 B Orange & 29 A Orange \\
\hline$T_{10}$ & Rose pink $-4 \%$ & N 155 D White & N 155 B White & N 155 A White \\
\hline$T_{11}$ & Rose pink $-8 \%$ & N 155 B White & N 155 C White & N 155 B White \\
\hline $\mathbf{T}_{12}$ & Raspberry red $-4 \%$ & 49 B Red & 49 B Red & 49 B Red \\
\hline $\mathbf{T}_{13}$ & Raspberry red $-8 \%$ & $49 \mathrm{C}$ Red & $49 \mathrm{C}$ Red & 49 C Red \\
\hline
\end{tabular}


Fig.1 Color intensity of tuberose spikes as influenced by different food dyes

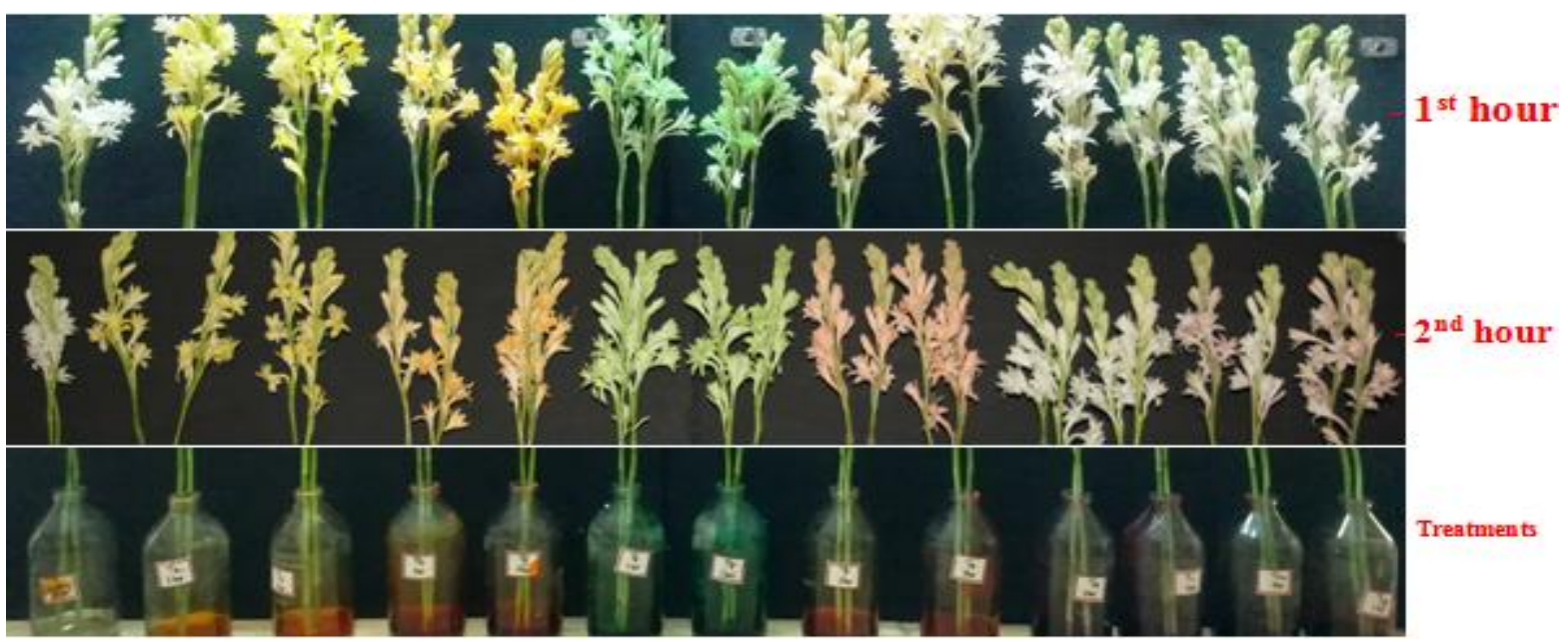

Fig.2 Color intensity of tuberose florets after 2 hours immersion time in food dyes

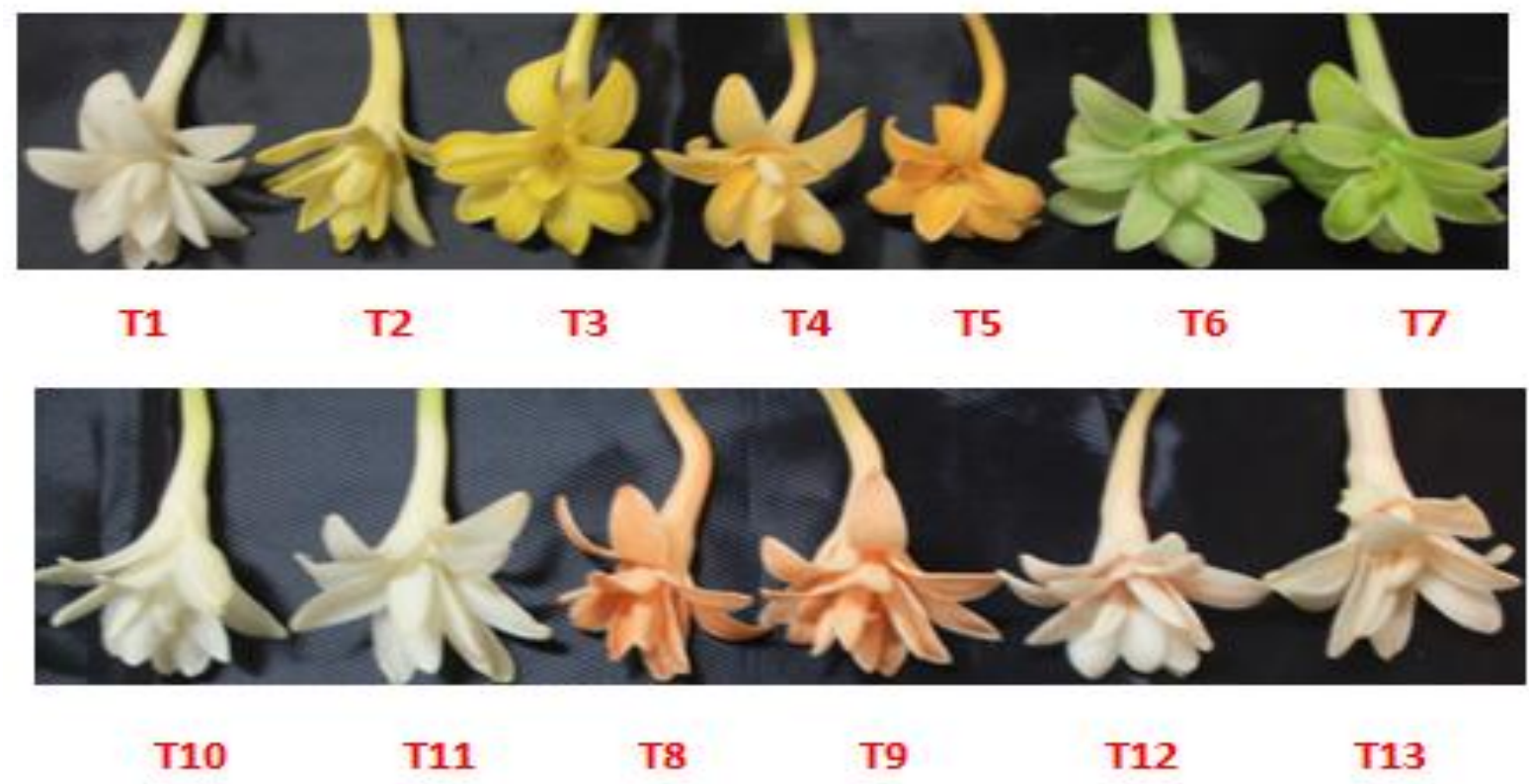

However, time of immersion did not show any significant difference. Whereas, the interaction effect of food dye and time of dipping showed significant difference. The floret diameter did not differ significantly due to food dye concentration and immersion time.

Vase life did not differ significantly in respect of food dyes, whereas it differed significantly due to time of immersion and interaction between food dye and time (Table 3 ). The mean maximum vase life (4.48 days) was recorded in the spikes immersed for one hour duration and was on par with two hour duration (3.96 days). However, minimum vase life (3.78 days) was registered in three hours duration of immersion time. This might be due the lower time of immersion of spikes lead to lower intake of dye with less 
concentration in turn resulted in free movement of water during vase life period. In the similar lines, the interaction effect of food dye and time was also found significant. The control treatment (Distilled water) with one hour immersion recorded maximum vase life (5.12 days) and was on par with other food dye treatments in one hour duration of dipping. The time of immersion influenced the vase life higher the duration of dipping the vase life was lower, longer time immersion might have disturbed the cellular metabolism of conductive tissues and obstructed the movement of vase solution during the vase life period. Similar results were reported by Sweta Kumari and Prahlad Deb (2018) in Tuberose cv. Prajwal. However, Safeena et al., (2016) reported degree of immersion time did not differ the vase life with different food dye in tube rose and Sudha and Harshal (2008) in candytuft.

Colour intensity differed due to colour of food dye and time of immersion, in almost all the food dyes two hours immersion imparted appreciable coloration compared to one and three hours (Table 4, Fig. 1 and 2). The food dyes with higher concentration of 8 per cent resulted in darker colouration than lower concentration based on the RHS colour chart and visual observation. The flower spikes dipped in Kesar yellow, apple green and orange red at 8 per cent developed maximum intensity of colour and it was higher up to two hours of dipping. Similar result of higher concentration with higher absorption time was also reported by Viradia et al., (2015) in tuberose cv. Double.

From the above study, it can be inferred that, tinting is the very suitable technique to impart colouring to tube rose flower spikes by using safe edible food dyes. The food dyes at higher concentration of 8 per cent imparted darker shades of colour to the tube rose florets with two hours of immersion time. The lemon yellow, Kesar yellow, Apple green was found promising to produce attractive colours to tuberose florets based on color intensity.

\section{References}

Kumar, V., and Bhattacharjee, S. K., 2004. Influence on coloring agents on postharvest life and quality of tuberose spikes. Scientific Hort. 9:187-191

Mekala, P., Ganga, M., and Jawaharlal, M., 2012. Artificial colouring of tuberose flowers for value addition. South Ind. Hort. 60: 216 - 223.

Safeena, S. A., Thangam, M., and Singh, N. P., 2016. Value addition of tuberose (Polianthes tuberosa L.) spikes by tinting with different edible dyes. Asian jr. of res. in biological and pharma. sci. 4(3):89-98

Sambandhamurthy, S., and Appavu, K., 1980. Effect of the Chemical on Coloring of tuberose (Polianthes tuberosa L.,) Proc. of National Seminar on Production Technology for Commercial Flower Crops, TNAU, Coimbatore, Tamilnadu, India, pp 73-75.

Sowmeya, S., Humaresan, S., and Sanmuga Priya, L., 2017. Effect of multi colours in tinting techniques in cut flowers (Rose and Carnation). Chemical Sci. Rev. and Lett., 6 (24): 2250-2253

Sudha, D. Patil, and Harshal, E. Patil., 2008. Value addition of candytuft (Ibres umbellate L.) cut flowers coloued with edible dyes. Asian Journal of Bio Sci., 3(1): 163-167.

Suresh Chougala, B., Hemla Naik, Shivayya, M., Savita, K. H., and Shivakumar., 2016. Effect of tinting on florets drop of cut tuberose spikes. International Jr. of current Res., 8(3): 27206-27208.

Sweta Kumari, and Prahlad Deb., 2018. Effect of tinting on value addition of tuberose (Polianthes tuberosa L.) cv. Prajwal. International Journal of Bio- 
Resource and Stress Management. 9(3): 314-322.

Viradia, R. R., Bajad, A., Polara, N. D., 2015. Value addition through use of ye chemicals and Floral preservatives in Tuberose (Polianthes tuberosa L.) cv. Double. International Jr. of Forestry and Hort. 1(1): 1-4.

\section{How to cite this article:}

Prasanth, P., Z. Salma and Praneeth Kumar, S. 2020. Tinting Efficiency of Various Food Dyes in Colour Intensification of Tuberose (Polianthes tuberose L.) Spikes. Int.J.Curr.Microbiol.App.Sci. 9(09): 1545-1551. doi: https://doi.org/10.20546/ijcmas.2020.909.195 